\title{
The Influence of Core Enterprise's Network Power on Breakthrough Innovation
}

\author{
Lu Chen*, Jinsheng Li \\ School of Business, Nanjing Normal University, Nanjing 210046, China \\ *Correspondence Author
}

\begin{abstract}
In the process of industrial upgrading, Chinese manufacturing enterprises are facing intense competitive pressures from within and even between industries worldwide, and breakthrough innovation has become the key to survival and development of enterprises. Based on social network theory and resource-based theory, this paper discusses the relationship between network power, supplier innovation capability and breakthrough innovation of core manufacturing enterprises under supplier network from the perspective of power dependence. The results show that the resource power, structural power and institutional power of core enterprises have a significant positive impact on process breakthrough innovation, and the resource power, structural power and institutional power of core enterprises also have a significant positive impact on product breakthrough innovation. Supplier innovation ability plays a partial mediating role between the network power of core enterprises and breakthrough innovation.
\end{abstract}

Keywords: Network power, Supplier innovation ability, Breakthrough innovation.

\section{Introduction}

In the process of industrial upgrading, Chinese manufacturing enterprises are facing intense competitive pressures from industries worldwide, and breakthrough innovation has become the key to survival and development of enterprises. Although breakthrough innovation is crucial to a company's growth and maintaining a sustainable competitive advantage, it is often difficult for companies to independently commercialize breakthrough technologies, due to complex product composition, long R\&D cycles, and lack of resources. Companies often need external help, and external resources from corporate partners can help overcome resource constraints in the process of breakthrough innovation. Supplier network can provide enterprises with the latest technology, knowledge, etc., and is an important source of external resources for enterprises' innovation activities. However, how to better obtain resources from the supplier network and enhance the breakthrough innovation ability of enterprises has become an urgent issue for high-tech enterprises.

Regarding the relationship between network power and the breakthrough innovation of core enterprises, domestic and foreign scholars mainly conduct research on the impact of network power on breakthrough innovation, and put forward three views:(1) The positive impact of network power on breakthrough innovation performance. Fang Ran (2018) believes that corporate network power uses the dependence between the subject and the object to influence and control the decisions and behaviors of both parties, so as to achieve the main goal of improving cooperation performance by coordinating the relationship between the two parties. Kähkönen (2014) believes that the actors who occupy an absolute position in the network can dominate the cooperation model, and at the same time, they are highly efficient, easy to be imitated and can reduce the transaction cost in the process of cooperation. Ma Lan (2016) believes that the richer the enterprise has rich collaboration experience, the greater the network power, which is more conducive to improving the innovation performance of the enterprise. Akbar (2005) and others believe that both the innovation capability and the network structure of the enterprise can improve the performance of the enterprise, and the enterprise needs to develop the network capability that can make up for the structural loopholes. (2) The mediating effect of network power on enterprise performance. Phelps (2010) examined the influence of the structure and composition of the enterprise alliance network on its exploratory innovation, and the network density among enterprise alliance partners played a positive moderating role between technological diversity and exploratory innovation. Wang Hecheng (2019) believes that network power plays a mediating role in the relationship between network embeddedness and firms' innovation performance. Li $\mathrm{Na}$ (2018) believes that the size of an enterprise's network power affects the supplier's resource allocation to the enterprise and the innovation contribution to the enterprise. (3) The promotion effect of network power on enterprise innovation behavior. Dai Wanliang (2016) believes that core enterprises use network power to influence the technological innovation behaviors of other network members in the cluster under the guidance of the market and the diffusion of technical standards. Zhao et al. (2008) argue that the proper use of network power can significantly enhance relational commitment. Improving relationship commitment, especially normative relationship commitment, can improve a company's competitive advantage.

Existing studies have shown that network power has a positive role in promoting technological innovation of enterprises, but there is a lack of relevant research on the internal mechanism of how network power affects breakthrough innovation. Core enterprise network power can improve the efficiency of network resource allocation. At the same time, it plays an important role in the utilization efficiency of the supplier's innovation ability and the breakthrough innovation performance of the enterprise. Therefore, based on resource-based theory and social network theory, this study explores the relationship between different network powers of core firms and breakthrough innovation, with supplier innovation capability as an intermediary and analyzes the effect mechanism of core enterprise network power on breakthrough innovation performance, and provides useful enlightenment for the healthy development of core 
enterprise and supplier management practice.

\section{Theoretical Basis}

In a supplier network, network power evolves from the power of network organization members to cross corporate boundaries. Scholars believe that network power is generally embodied in "control" and "influence." Ireland (2007) believes that network power is an ability embedded in a social network to influence the behavior of other subjects for the purpose of self-interest. The interrelationship and mutual influence of each other. Sun Guoqiang (2018) believes that the characteristics of network power are not single, but present multiple characteristics of multidimensionality, asymmetry, interdependence, and dynamic evolution. This article believes that the network power under the supplier network is caused by the asymmetry of corporate resources and the unequal structure of the company under the supplier network, and the manufacturing company's ability to influence and control other members for the purpose of its own interests. Drawing lessons from Wang Qin's (2012) explanation of the source of power in network organizations, the dimensions of supplier network power are divided into: resource power, structural power, and institutional power.

\subsection{Network Power}

In a supplier network, network power evolves from the power of network organization members to cross corporate boundaries. Scholars believe that network power is generally embodied in "control" and "influence." Ireland (2007) believes that network power is an ability embedded in a social network to influence the behavior of other subjects for the purpose of self-interest. The interrelationship and mutual influence of each other. Sun Guoqiang (2018) believes that the characteristics of network power are not single, but present multiple characteristics of multidimensionality, asymmetry, interdependence, and dynamic evolution. This article believes that the network power under the supplier network is caused by the asymmetry of corporate resources and the unequal structure of the company under the supplier network, and the manufacturing company's ability to influence and control other members for the purpose of its own interests. Drawing lessons from Wang Qin's (2012) explanation of the source of power in network organizations, the dimensions of supplier network power are divided into: resource power, structural power, and institutional power.

(a) Resource power. The resource power of the core enterprise is the ability of the core enterprise to influence and control other enterprises in the supplier network based on its own control of important resources for the survival and development of the entire supplier network. Enterprise endogenous resources have an important influence on the size of its power in the network. Power resources are scarce, irreplaceable and indispensable. The more important resources that a core enterprise has for the survival and development of the entire network, the greater its network power.

(b) Structural power. The structural power of the core enterprise is the ability of the core enterprise to take advantage of its position in the center of the network to control the information and knowledge in the supplier network. Structural power stems from the structural characteristics of the interaction between members in the supplier network. Existing studies have shown that network power comes from the network structure or the position of nodes in the network, which determines the size of the power of cooperative enterprises, so that structural power becomes synonymous with power. In the supplier network, the core enterprise has a high status and a strong sense of status, and knows how to use the power brought by its network location to seek benefits.

(c) Institutional power. The institutional power of the core enterprise refers to the influence and restraint effect of the core enterprise on the behavior and activities of other members in the network organization by using itself as the core industry standards and network norms. Institutional power comes from organizational practices, laws and regulations, culture, concepts and systems. These factors may affect the behavior and decision-making of network participants. These internal and external forces merge together to form a binding "network norm" (Wang Qin, 2012). The institutional power of the core enterprise is manifested in that the core enterprise uses industry norms to restrict the supplier's product standards and technical standards, so that the supplier can produce components that meet the requirements of the core enterprise.

\subsection{Supplier Innovation Ability}

Innovation ability is the ability of an enterprise to dynamically configure a variety of elements to help the enterprise explore and develop new opportunities to successfully implement new ideas and new processes. Innovation ability can effectively promote the smooth development of company entrepreneurial activities (Zhao Ling et al., 2020). Li Rui and Tao Qiuyan (2016) believe that the supplier's ability to innovate reflects the supplier's ability to develop and introduce new products or new processes. Ability to use new business models. Li Na and $\mathrm{Li}$ Suicheng (2017) believe that cooperation with innovative suppliers will improve the performance of new products. As the core company in the supplier network wants to create value and achieve innovation performance, suppliers need to improve their own innovation capabilities and innovate raw materials from the source.

\subsection{Breakthrough Innovation}

Abenathy \& Utterback (1978) pioneered the concept of breakthrough innovation, believing that breakthrough innovation is a new innovation model that is completely different from other innovations. It adopts new $R \& D$ technology, injects new ideas, develops brand-new products and opens up a whole new market. The main characteristics of breakthrough innovation are: (1) Discontinuity in the technological path. Breakthrough innovation is an innovation with discontinuous characteristics based on brand new knowledge. It takes a technological path completely different from the original technological development path and completely interrupts the original path. (2) The subversive nature of market demand. Breakthrough innovation can create new needs for users, and make fundamental changes in user value propositions and value acquisition methods, thereby helping core companies develop new markets and cultivate 
new customers. (3) Uncertainty of innovation results. In terms of technology, breakthrough innovation is not an improvement to existing technological paths or technical problems, but some unexpected opportunities and problems, opening up a new technological track, and the result of the development is not certain. At the same time, in the market, breakthrough innovation is not aimed at satisfying the needs of existing users, but is geared towards new markets, with uncertain profit cycles. Therefore, the results of breakthrough innovation have high uncertainty and high risk.

This article uses Utterback (1994) to divide the dimension of breakthrough innovation, and divides its dimensions into process breakthrough innovation and product breakthrough innovation.

(a) Process breakthrough innovation mainly refers to the major changes or breakthroughs in the process, technology and knowledge of the core enterprise in the product manufacturing process, and the core enterprise has subverted the technology and knowledge link structure, which is conducive to the production cost of the core enterprise. Process breakthrough innovation is not focused on the improvement of the technical route or knowledge link structure, but on the unexpected problems, trying to subvert the existing technological track and enter a new technological track, which is uncertain. Such as: core enterprises' innovations in production equipment, process flow, management control system, operational effectiveness, etc.

(b) Product breakthrough innovation mainly refers to the development of new products with main performance indicators different from the past by core companies, and the effect of new products or services on existing or potential markets, which is conducive to core companies to obtain sustainable competitive advantages in long-term competition. Irreplaceable products may appear in breakthrough innovations. Such products are irreversible and possess a new technology-led paradigm, which replaces certain original products and makes them eventually eliminated by the market. For example, electric light replaces the lighting effect of candles. The performance of product breakthrough innovation includes: the number of new product research and development, the degree of new product market development, the quality of new products, and the user satisfaction of new products.

\section{Research Hypothesis}

\subsection{Core Enterprise's Network Power and Process Breakthrough Innovation}

The uncertainty of the external environment and the scarcity of resources make the members of the network organization depend on each other in terms of resources, and have the characteristics of asymmetry. Due to the heterogeneity and differences of resources, the power of each network member is not equal. Those enterprises that hold key resources cause other network members to rely on it and enjoy power. In the supplier network, if the core enterprise wants to innovate in production equipment, process flow, management control system, etc., it will inevitably need a lot of resources. The core enterprise has a large amount of key knowledge, capital, social capital, and R\&D talents, and can use its own resource power in the network to mobilize the resources of the entire network to the greatest extent, so as to enhance the process breakthrough innovation of the core enterprise.

For a network organization, the structure determines its status, and the centrally located enterprise has a strong structural network power. Studies have shown that power is related to network centrality. Sun Guoqiang et al. (2018) believe that centrality is a key variable to measure network location, and network power describes the location relationship between network nodes. Zhang Yigong et al. (2017) found that network centrality has a positive impact on breakthrough innovation. The higher the centrality of the enterprise network, the more it can promote the optimization and integration of resources, thereby increasing the possibility of achieving breakthrough innovation. In the supplier network, the core enterprise is in the center of the network, the greater its structural network power, the greater the control and influence on other network members in the supplier network, the more the core enterprise can accelerate the absorption of knowledge and integrate resources. Promote breakthrough innovation.

An enterprise is not only a product of capital but also a product of the system. Any company must be in an institutional environment recognized by the society. The system restricts the enterprise through a conventional operating mechanism. Companies are required to adopt practices that are widely accepted in a certain institutional environment, regardless of whether these practices are meaningful to the operational efficiency of the company, to ensure that the behavior of the company is consistent with popular norms established by conventions (Wang Qin, 2012). The core enterprise uses its own institutional power in industry norms and technical standards to require network members to innovate products in accordance with their standards, and supplement resources for the core enterprise's breakthrough innovation in the process, which is conducive to shortening the time for breakthrough innovation in the enterprise process and improving the enterprise process The efficiency of breakthrough innovation. Based on this, hypothesis 1:

H1: Network power has a significant positive impact on process breakthrough innovation.

H1a: Resource power has a significant positive impact on process breakthrough innovation.

H1b: Structural Power has a significant positive impact on process breakthrough innovation.

H1c: Institutional power has a significant positive impact on process breakthrough innovation.

\subsection{Core Enterprise's Network Power and Product Breakthrough Innovation}

The network power under the supplier network is caused by the asymmetry of enterprise resources and the unbalanced structural situation in the supplier network. The core enterprise influences and controls the ability of other 
members for the purpose of its own interests. The more core the core enterprise occupies in the supplier network, the more resources it has, which is conducive to the breakthrough innovation of the core enterprise. The greater the power of the core enterprise's resource network means that the core enterprise has more important and irreplaceable scarce and valuable resources for the survival and development of the entire supplier network, including talents and knowledge. The core enterprise can invest a large amount of funds in the process of technology research and development, and at the same time apply the rich knowledge resources in the core enterprise's own knowledge base to product innovation, and mobilize the resources in the network to promote the core enterprise's product breakthrough innovation.

The core enterprise interacts and communicates with other organization members in the supplier network. The core enterprise in the core position participates in and dominates the advancement and development of the supplier network, and has absolute control over its affiliated enterprises and sub-enterprises. The core enterprise uses its own structural power to manage the information flow and capital flow of the entire network, promotes the cooperation and communication between other members of the network and itself, and improves the speed and success rate of the core enterprise's new product development.

Each industry has its own industry standards. The core companies use their own technological advantages and the position of the "leading boss" in the industry to establish industry norms centered on the core companies, resulting in institutional power. Institutional power is manifested in that core enterprises use industry norms to restrict suppliers' product standards and technical standards, so that suppliers can produce components that meet the requirements of core manufacturers. Institutional power comes from organizational conventions, laws and regulations, culture, concepts and systems, etc. These factors may affect the behavior and decision-making of network participants. These internal and external forces merge together to form a binding "network norm." The system is compulsory and deterrent. The core enterprises occupying the key links of the supplier network use institutional power to coordinate the value creation activities of upstream and downstream enterprises within the network, forming certain constraints and influences on the upstream and downstream enterprises. By signing technical cooperation agreements with suppliers, core enterprises can achieve the effect of resource integration, which is conducive to the absorption of new technological resources by core enterprises, thereby improving product development and innovation capabilities, and is conducive to the improvement of breakthrough innovation performance. Based on this, hypothesis 2 :

$\mathrm{H} 2$ : Network power has a significant positive impact on product breakthrough innovation.

H2a: Resource power has a significant positive impact on product breakthrough innovation.

H2b: Structural Power has a significant positive impact on product breakthrough innovation.
H2c: Institutional power has a significant positive impact on product breakthrough innovation.

\subsection{Core Enterprise's Network Power and Supplier Innovation Ability}

Network power stems from the imbalance of the network structure and the asymmetry of resource dependence. Construct the supplier network structure, deal with the interdependent relationship between the enterprise and other network members, and other network members. The core enterprise can effectively realize the control of key resources such as the actions and knowledge of other network members in the supplier network ( $\mathrm{Li} \mathrm{Na}$, etc., 2018). Resources play a vital role in the improvement of suppliers' innovation capabilities, but suppliers rely solely on their own internal resources, which makes innovation difficult. With the help of its resource advantages, core enterprises can share resources with suppliers and achieve resource integration. The resource power of core enterprises can help suppliers obtain the resources needed in the innovation process, help suppliers improve their competitiveness, and thus encourage suppliers to actively innovate and enhance their innovation capabilities. The core enterprise integrates different forms of network connections and controls key resources, and controls the direction and intensity of knowledge flow in the network. This makes the network suppliers dependent on the core enterprise that has key resources, and improves the irreplaceability of the core enterprise in the network. Sex (Owen-Smith et al., 2004). The use of resource power by core enterprises makes suppliers dependent on core enterprises, and promotes the integration of internal and external resources of suppliers, increases suppliers' knowledge stock, creates conditions for supplier innovation, and is conducive to the improvement of suppliers' innovation capabilities.

Existing studies have shown that network power comes from the network structure or the position of nodes in the network, which determines the size of the power of cooperative enterprises, so that structural power becomes synonymous with power. The size of the centrality and the number of structural holes determine the network status of a company. A company with a strong status awareness knows how to use the power brought by its network status to seek benefits. The core enterprise in the supplier network takes advantage of its position in the center of the network to have the ability to control the information and knowledge in the supplier network. The structural power in the supplier network originates from the structural characteristics of the interaction between members in the supplier network. The core enterprise has an influence and control over the behavior of other organization members due to its dominant position in the network organization. Core enterprises located in the center of advantage rely on their strong industry influence and excellent strength, and often have greater options in the choice of partners. Therefore, in order to maintain the cooperation with the core enterprise that is located in the central position and holds the structural power, the supplier must keep up with the pace of the core enterprise and continue to innovate. Based on this, hypothesis 3 :

H3: Network power has a significant positive impact on supplier innovation ability. 
H3a: Resource power has a significant positive impact on supplier innovation ability.

H3b: Structural Power has a significant positive impact on supplier innovation ability.

$\mathrm{H} 3 \mathrm{c}$ : Institutional power has a significant positive impact on supplier innovation capability.

\subsection{Supplier Innovation Ability and Breakthrough Innovation}

Suppliers with innovative ability can make more innovative contributions to the breakthrough innovation of core enterprises, and can provide new knowledge, technology and component support for core enterprises in the process of breakthrough innovation of core enterprises, so that core enterprises can produce new products and occupy a significant position in existing or potential markets. Supplier innovation is an important supplement to the existing knowledge, technology and resources of core enterprises (Pulles et al., 2014). Based on the resource view, knowledge is an indispensable resource in the process of breakthrough innovation of core enterprises. In the supplier network, suppliers with strong innovation capabilities often have relatively large reserves of knowledge, and core enterprises can often obtain complementary knowledge from innovative suppliers. Heterogeneous and complementary knowledge resources can promote the subversion of core enterprises in terms of technology and knowledge link structure. Core enterprises outsource the business of components to innovative suppliers, and core enterprises can learn the professional technology of innovative suppliers and learn the ideas of suppliers in the process of product breakthrough innovation. Utilize the resources, knowledge and professional technology mastered by suppliers with their innovative achievements, so as to improve the process of core enterprise process innovation and product innovation, enhance new product innovation capabilities, and thus improve product breakthrough innovation performance. Supplier innovation is the source of value for core enterprises. Using suppliers to transfer knowledge and skills can provide core enterprises with innovative methods and solutions for product development. Based on this, hypothesis 4:

H4: Supplier innovation ability has a significant positive impact on breakthrough innovation.

H4a: Supplier innovation ability has a significant positive impact on process breakthrough innovation.

H4b: Supplier innovation ability has a significant positive impact on product breakthrough innovation.

\subsection{The Mediating Role of Supplier's Innovation Ability}

The manifestations of the supplier's innovation ability include the supplier's development of new components and the adoption of new processes, which are crucial to the breakthrough innovation of core enterprises. There are two sources of manufacturers' innovation ability: one is directly from the innovation of suppliers, and the other is indirectly from the mutual learning between manufacturers and suppliers (Huang Yuzhou et al., 2013). Core enterprises make suppliers rely on power through network power, and use their own key resources, network core position advantages and "network norms" to urge suppliers to keep up with the pace of core enterprise innovation, and strive to improve innovation capabilities. On the one hand, suppliers with innovative capabilities are more likely to produce key components or key raw materials required by the core enterprise's breakthrough innovation. The innovation has contributed to the production of new products of the core enterprise. On the other hand, suppliers with strong innovation ability have more knowledge reserves in the knowledge base, and core enterprises can obtain more heterogeneous and complementary knowledge and resources from innovative suppliers, thereby improving the process of core enterprise product production and technological process innovation, break through the limitations of core enterprises and promote the breakthrough innovation of core enterprises. Therefore, core enterprises have an impact on supplier innovation through network power, prompting suppliers to improve their innovation capabilities, and using suppliers' innovation to enhance core enterprises breakthrough innovation capabilities. Based on this, hypothesis 5:

H5: Supplier innovation ability plays an intermediary role between network power and breakthrough innovation.

H5a: Supplier innovation ability plays an intermediary role between resource power and breakthrough innovation.

H5b: Supplier innovation ability plays an intermediary role between structural power and breakthrough innovation.

H5c: Supplier innovation ability plays an intermediary role between institutional power and breakthrough innovation.

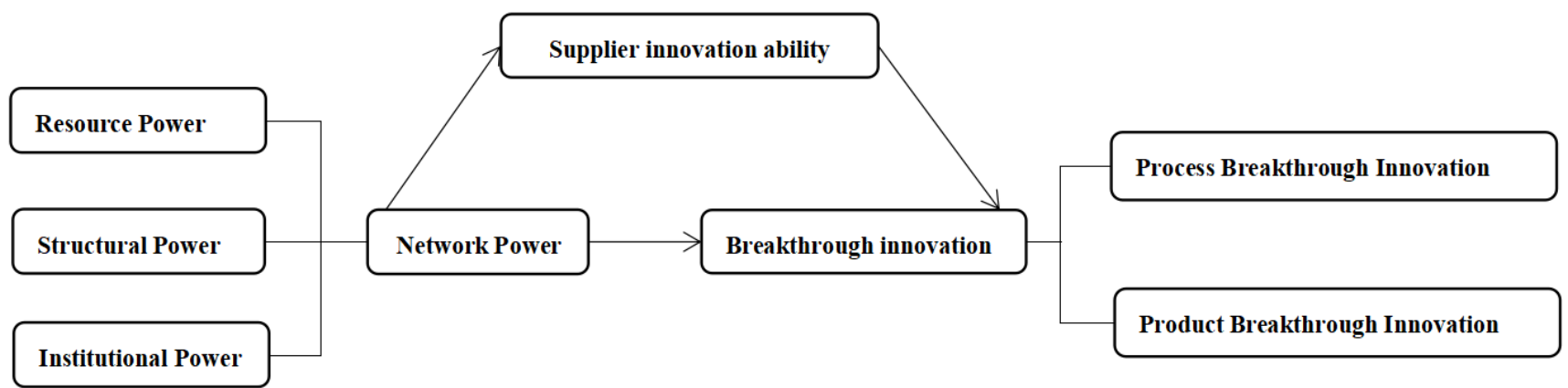

Figure 1: Concept model 


\section{Research Design}

\subsection{Samples and Data}

Core enterprises use network power to drive supplier innovation, aiming to meet core needs and achieve breakthrough innovation. Core enterprises use network power to promote innovation of suppliers, aiming to meet core needs and achieve breakthrough innovation. Therefore, in order to verify the research hypothesis of this paper, high-tech manufacturing enterprises are taken as the research objects, geographically distributed in areas with frequent innovation activities, mainly involving manufacturing enterprises in Beijing, Jiangsu Province, Guangdong Province and other provinces (cities). Send questionnaires to high-tech manufacturing enterprises nationwide (including: Beijing, Jiangsu Province, Guangdong Province, etc.) through E-mail and field research. A total of 375 questionnaires were sent. After excluding invalid questionnaires, 267 valid questionnaires were finally obtained, the effective recovery rate was $71.2 \%$.

\subsection{Variable Measurement}

The variable measurement items in this paper mainly refer to and draw lessons from mature scales at home and abroad, and all items are measured by a 7-point Likert scale (1 means complete disagreement, 7 means complete agreement). Drawing on Ireland (2007) and Wang Qin (2012) on the dimensional division of network power, combined with the views and opinions of other scholars, the network power is divided into resource power, structural power, and institutional power. With reference to the scales of Dang Xinghua (2013) and Han Ying (2016), and combined with the actual situation, the measurement items were added and modified to make the measurement items as complete as possible. The questionnaire contains 12 measurement items in three dimensions. According to the research needs, we use Keskin (2006) and Li Na (2018) to measure the innovation ability of suppliers, with a total of 4 items. Drawing on the dimension division of Utterback (1994), the breakthrough innovation is divided into process breakthrough innovation and product breakthrough innovation, and drawing on the measurement items of You Daming (2014), Gemünden (1996) and Zhou (2005), etc., a total of 8 items measurement items. Finally, this paper takes the size of the enterprise as a control variable and measures it with the number of employees.
In this study, the internal consistency coefficient Cronbach's $\alpha$ and combined reliability (CR) were used to test the reliability of each variable, as shown in Table 1 . The $\alpha$ value of each variable was between $0.800-0.930$, all exceeding 0.700 , and the CR value was between 0.871-0.952, all higher than 0.600 , showing high internal consistency. The KMO values of the overall scale and each dimension ranged from 0.731 to 0.938 , all exceeding 0.700 , and the corresponding $p$ values were all less than 0.001 , indicating that the scale had good construct validity.

Table 1: Variable reliability and validity test

\begin{tabular}{|c|c|c|c|c|c|}
\hline Variable & Dimension & $\begin{array}{c}\text { Cronbach's } \\
\alpha\end{array}$ & KMO & CR & $\mathrm{P}$ \\
\hline \multirow{4}{*}{ Network power } & $\begin{array}{l}\text { Resource } \\
\text { power }\end{array}$ & 0.895 & 0.816 & 0.927 & 0 \\
\hline & $\begin{array}{l}\text { Structural } \\
\text { power }\end{array}$ & 0.8 & 0.731 & 0.871 & 0 \\
\hline & $\begin{array}{c}\text { Institutional } \\
\text { power }\end{array}$ & 0.837 & 0.781 & 0.894 & 0 \\
\hline & Total & 0.93 & 0.928 & 0.94 & 0 \\
\hline $\begin{array}{l}\text { Supplier } \\
\text { innovation ability }\end{array}$ & Total & 0.919 & 0.844 & 0.945 & 0 \\
\hline \multirow{3}{*}{$\begin{array}{l}\text { Breakthrough } \\
\text { innovation }\end{array}$} & $\begin{array}{c}\text { Process } \\
\text { breakthrough } \\
\text { innovation }\end{array}$ & 0.849 & 0.836 & 0.899 & 0 \\
\hline & $\begin{array}{c}\text { Product } \\
\text { breakthrough } \\
\text { innovation } \\
\text { innovation }\end{array}$ & 0.897 & 0.784 & 0.932 & 0 \\
\hline & Total & 0.922 & 0.923 & 0.952 & 0 \\
\hline
\end{tabular}

\section{Empirical Analysis}

\subsection{Descriptive Statistics and Correlation Analysis}

Correlation analysis is carried out on the three dimensions of network power, supplier innovation capability, and two dimensions of breakthrough innovation, and the mean, standard deviation and Pearson Correlation of each variable and dimension are obtained in Table 2. It can be seen from the table that there is a significant positive correlation between resource power, structural power, institutional power and breakthrough innovation, and there is a significant positive correlation between resource power, structural power, and institutional power and supplier innovation ability, provides a preliminary justification for the rationality of the model and assumptions. The VIF test is carried out on the variables, and the maximum VIF value of each variable is 3.094, which is less than 10. Therefore, there is no obvious collinearity problem between the variables.

\subsection{Reliability and Validity Analysis}

Table 2: Variable descriptive statistics and correlation coefficient

\begin{tabular}{|c|c|c|c|c|c|c|c|c|c|c|}
\hline Variable & Mean & standard deviation & 1 & 2 & 3 & 4 & 5 & 6 & 7 & 8 \\
\hline $\begin{array}{c}\text { Breakthrough } \\
\text { innovation }\end{array}$ & 4.332 & 1.271 & 1 & & & & & & & \\
\hline $\begin{array}{l}\text { Process breakthrough } \\
\text { innovation }\end{array}$ & 4.154 & 1.336 & $0.943^{* *}$ & 1 & & & & & & \\
\hline $\begin{array}{l}\text { Product breakthrough } \\
\text { innovation }\end{array}$ & 4.509 & 1.358 & $0.945^{* *}$ & $0.782^{* *}$ & 1 & & & & & \\
\hline $\begin{array}{l}\text { Supplier innovation } \\
\text { ability }\end{array}$ & 4.343 & 1.24 & $0.796^{* *}$ & $0.728^{* *}$ & $0.774^{* *}$ & 1 & & & & \\
\hline Resource power & 4.45 & 1.165 & $0.823^{* *}$ & $0.737^{* *}$ & $0.816^{* *}$ & $0.744^{* *}$ & 1 & & & \\
\hline Structural power & 4.185 & 1.468 & $0.871^{* *}$ & $0.851^{* *}$ & $0.793^{* *}$ & $0.675^{* *}$ & $0.737^{* *}$ & 1 & & \\
\hline Institutional power & 4.378 & 1.342 & $0.783^{* *}$ & $0.667^{* *}$ & $0.810^{* *}$ & $0.717^{* *}$ & $0.774^{* *}$ & $0.692^{* *}$ & 1 & \\
\hline Enterprise size & 3.99 & 2.122 & 0.03 & -0.003 & 0.058 & 0.008 & 0.055 & 0.07 & $0.131^{*}$ & 1 \\
\hline
\end{tabular}

Note: $\mathrm{N}=267,{ }^{*} \mathrm{p}<0.05, * * \mathrm{p}<0.01, * * * \mathrm{p}<0.001$. 


\subsection{Main Effect Test}

In order to test the relationship between network power and process breakthrough innovation, three dimensions of control variables and independent variables were introduced into the model, and the analysis results are shown in Table 3. After controlling for firm size, resource power has a significant positive impact on process breakthrough innovation (M2: $\beta=0.740, p<0.001$ ), hypothesis H1a is verified; structural power has a significant positive impact on process breakthrough innovation (M3: $\beta=0.855, p<0.001$ ), hypothesis $\mathrm{H} 1 \mathrm{~b}$ is validated; institutional power has a significant positive impact on process breakthrough innovation (M4: $\beta=0.679$, $\mathrm{p}<0.001$ ), hypothesis $\mathrm{H} 1 \mathrm{c}$ is validated. In addition, with the addition of institutional power in Model 4, firm size has a negative impact on process breakthrough innovation (M4: $\beta=-0.092, p=0.047<0.05)$. It shows that institutional power may play a positive role in the relationship between enterprise scale and process breakthrough innovation.

Table 3: Regression analysis results of core enterprise network power and process breakthrough innovation

\begin{tabular}{ccccc}
\hline \multirow{2}{*}{ Variable } & \multicolumn{3}{c}{ Process breakthrough innovation } \\
\cline { 2 - 4 } & Model 1 & Model 2 & Model 3 & Model 4 \\
\hline Firm size & -0.003 & -0.043 & -0.062 & $-0.092^{*}$ \\
Resource power & & $0.740^{* * *}$ & & \\
Structural power & & & $0.855^{* * *}$ & \\
Institutional power & & & $0.679^{* * *}$ \\
$\mathrm{R}^{2}$ & 0 & 0.545 & 0.728 & 0.453 \\
$\mathrm{~F}$ & 0.002 & $158.277^{* * *}$ & $352.998^{* * *}$ & $109.243^{* * *}$ \\
$\Delta \mathrm{R}^{2}$ & 0 & 0.545 & 0.728 & 0.453 \\
\hline Note: $\mathrm{N}=267,{ }^{*} \mathrm{p}<0.05, * * \mathrm{p}<0.01, * * * \mathrm{p}<0.001$. & &
\end{tabular}

Similarly, three dimensions of control variables and independent variables are introduced into the model to test the relationship between network power and product breakthrough innovation. The analysis results are shown in Table 4. After controlling for firm size, resource power has a significant positive impact on product breakthrough innovation (M6: $\beta=0.816, p<0.001$ ), hypothesis $\mathrm{H} 2 \mathrm{a}$ is verified; structural power has a significant positive impact on product breakthrough innovation $(\mathrm{M} 7: \beta=0.793, \mathrm{p}<0.001$ ), hypothesis $\mathrm{H} 2 \mathrm{~b}$ is verified; institutional power has a significant positive impact on product breakthrough innovation (M8: $\beta=0.816, p<0.001$ ), hypothesis $\mathrm{H} 2 \mathrm{c}$ is verified.

Table 4: Regression analysis results of core enterprise network power and product breakthrough innovation

\begin{tabular}{ccccc}
\hline \multirow{2}{*}{ Variable } & \multicolumn{3}{c}{ Product breakthrough innovation } \\
\cline { 2 - 5 } & Model 5 & Model 6 & Model 7 & Model 8 \\
\hline Firm size & 0.058 & 0.014 & 0.003 & -0.049 \\
Resource power & & $0.816^{* * *}$ & & \\
Structural power & & & $0.793^{* * *}$ & \\
Institutional power & & & $0.816^{* * *}$ \\
$\mathrm{R}^{2}$ & 0.003 & 0.667 & 0.629 & 0.659 \\
$\mathrm{~F}$ & 0.907 & $264.045^{* * *}$ & $224.065^{* * *}$ & $254.623^{* * *}$ \\
$\Delta \mathrm{R}^{2}$ & 0.003 & 0.663 & 0.626 & 0.655 \\
\hline Note: $\mathrm{N}=267, * \mathrm{p}<0.05, * * \mathrm{p}<0.01, * * * \mathrm{p}<0.001$ & &
\end{tabular}

\subsection{Mediating Effect Test}

In order to test the relationship between network power and supplier innovation ability, three dimensions of control variables and independent variables are introduced into the model, and the analysis results are shown in Table 5. After controlling for firm size, resource power has a significant positive impact on supplier innovation capability (M10: $\beta=0.746, p<0.001$ ), hypothesis $\mathrm{H} 3 \mathrm{a}$ is verified; structural power has a significant positive impact on supplier innovation ability (M11: $\beta=0.678, p<0.001$ ), hypothesis $\mathrm{H} 3 \mathrm{~b}$ is validated; institutional power has a significant positive impact on suppliers innovation ability (M12: $\beta=0.728, \quad \mathrm{p}<0.001)$, hypothesis $\mathrm{H} 3 \mathrm{c}$ is validated. In addition, with the addition of institutional power in Model 12, firm size has a negative impact on suppliers innovation ability (M4: $\beta=-0.087$, $\mathrm{p}=0.043<0.05)$. It shows that institutional power may play a positive role in the relationship between firm size and supplier innovation ability.

Table 5: Regression analysis results of core enterprise network power and supplier innovation ability

\begin{tabular}{ccccc}
\hline \multirow{2}{*}{ Variable } & \multicolumn{3}{c}{ Supplier innovation ability } \\
\cline { 2 - 5 } & Model 9 & Model 10 & Model 11 & Model 12 \\
\hline Firm size & 0.008 & -0.033 & -0.039 & $-0.087^{*}$ \\
Resource power & & $0.746^{* * *}$ & & \\
Structural power & & & $0.678^{* * *}$ & \\
Institutional power & & & & $0.728^{* * *}$ \\
$\mathrm{R}^{2}$ & 0 & 0.555 & 0.457 & 0.521 \\
$\mathrm{~F}$ & 0.017 & $164.366^{* * *}$ & $111.158^{* * *}$ & $143.545^{* * *}$ \\
$\Delta \mathrm{R}^{2}$ & 0 & 0.555 & 0.457 & 0.521 \\
\hline Note: $\mathrm{N}=267, * \mathrm{p}<0.05, * * \mathrm{p}<0.01, * * * \mathrm{p}<0.001$ & &
\end{tabular}

Two dimensions of control variable and dependent variable are introduced into the model to test the relationship between supplier innovation ability and breakthrough innovation, see Table 6. After controlling for enterprise scale, supplier innovation ability has a significant positive impact on process breakthrough innovation (M14: $\quad \beta=0.729, \quad \mathrm{p}<0.001$ ), hypothesis $\mathrm{H} 4 \mathrm{a}$ is verified; supplier innovation ability has a significant positive impact on product breakthrough innovation (M15: $\beta=0.774, p<0.001$ ), hypothesis $\mathrm{H} 4 \mathrm{~b}$ is verified.

Table 6: Regression analysis results of supplier innovation capability and breakthrough innovation

\begin{tabular}{cccc}
\hline Variable & $\begin{array}{c}\text { Breakthrough } \\
\text { innovation }\end{array}$ & $\begin{array}{c}\text { Process } \\
\text { breakthrough } \\
\text { innovation }\end{array}$ & $\begin{array}{c}\text { Product } \\
\text { breakthrough } \\
\text { innovation }\end{array}$ \\
\cline { 2 - 4 } & Model 13 & Model 14 & Model 15 \\
\hline Firm size & 0.03 & -0.009 & 0.052 \\
Supplier & & & $0.774^{* * * *}$ \\
innovation & & 0.531 & 0.602 \\
ability & 0.001 & $149.266^{* * *}$ & $199.579^{* * *}$ \\
$\mathrm{R}^{2}$ & 0.233 & 0.531 & 0.598 \\
$\mathrm{~F}$ & 0.001 & & \\
$\Delta \mathrm{R}^{2}$ & &
\end{tabular}

In order to test the mediating effect of supplier innovation ability between core enterprise network power and breakthrough innovation, Baron's (1986) step-by-step test method was used to incorporate control variables, independent variables, mediator variables and dependent variables into the model. Table 7 shows: In the regression equation of the first step (resource power, structural power, and institutional power on breakthrough innovation), resource power, structural power, and institutional power all have significant positive effects on breakthrough innovation, and the regression coefficients are $0.273,0.523,0.216$, the corresponding $\mathrm{P}<001$; firm size has a negative impact on breakthrough innovation (M16: $\beta=-0.050, p=0.044<0.05$ ).In the regression equation of the second step (resource power, structural power, and institutional power on supplier innovation ability), resource power, structural power, and institutional power all have a significant positive impact on supplier innovation ability, and the regression coefficients are 
$0.364,0.364,0.200,0.305$, corresponding $\mathrm{P}<0.001$.In the regression equation of the third step (supplier innovation ability, resource power, structural power, and institutional power to breakthrough innovation), the supplier innovation ability is included in the regression, which proves that the mediating effect of supplier innovation ability exists (M18: $\beta=0.227, \quad p<0.001)$. On the one hand, resource power, structural power, and institutional power still have a significant positive impact on breakthrough innovation, and the regression coefficients are $0.191,0.478$, and 0.147 , respectively, with corresponding $\mathrm{P}<0.001$. On the other hand, the regression coefficients in the second and third steps of resource power, structural power and institutional power are all significant, corresponding $\mathrm{P}<0.001$.

In summary, supplier innovation ability plays a positive mediating role between resource power and breakthrough innovation, structural power and breakthrough innovation, and institutional power and breakthrough innovation. Supplier innovation ability plays a partial intermediary role between core manufacturing enterprise network power and breakthrough innovation, hypothesis $\mathrm{H} 5 \mathrm{a}, \mathrm{H} 5 \mathrm{~b}$, and $\mathrm{H} 5 \mathrm{c}$ are verified.

\section{Research Conclusion and Management Inspiration}

\subsection{Research Conclusion}

Based on social network theory and resource-based theory, this paper discusses the relationship between the network power, supplier innovation ability and breakthrough innovation of core enterprises under supplier network from the perspective of power dependence, and draws the following conclusions:

(a) Resource power has a positive effect on breakthrough innovation. The greater the resource power, the more key resources the core enterprise has for the survival and development of the entire supplier network, which makes the core enterprise have the core competitiveness in resources. At the same time, core enterprises have sufficient human, material and financial resources in $R \& D$ and master a lot of knowledge, which is conducive to the breakthrough innovation of core enterprises.

(b) Structural power has a positive effect on breakthrough innovation. The higher the degree of centralization of the core enterprise in the supplier network, the more connections it has with other members, and the connection path with other members is relatively short. Efficiently and accurately obtain abundant strategic resources, thereby promoting the breakthrough innovation of core enterprises.

(c) Institutional power has a positive effect on breakthrough innovation. Core enterprises use their own institutional power to standardize industry norms in network organizations, influence network routine, spread with the technical standards of core enterprises, form certain constraints and influences on upstream and downstream enterprises, and coordinate the value creation activities of upstream and downstream enterprises within the network. Improve the breakthrough innovation performance of core enterprises. (d) Supplier innovation ability plays an intermediary role in the influence of resource power, structural power and institutional power on breakthrough innovation. The resource power of core enterprises can help suppliers obtain the resources needed in the innovation process, realize resource sharing and integration with suppliers, and help suppliers improve their competitiveness, thereby motivating suppliers to innovate actively and enhancing their innovation ability. The core enterprises that hold structural power have strong comprehensive strength and industry influence, and can choose their partners independently. Therefore, in order to maintain the cooperation with the core enterprises that are located in the center and hold the structural power, the suppliers must keep up with the pace of the core enterprises, continuously innovate and improve their own innovation ability. Core enterprises use institutional power to urge suppliers to innovate in accordance with the network routine and industry standards formulated by core companies. The improvement of suppliers' innovation ability is conducive to their progress in the research and development of key raw materials, and contributes to the breakthrough innovation of core enterprises.

\subsection{Management Inspiration}

Core enterprises should strive to enhance the level of network power. With network power, core enterprises are more closely connected with other enterprises and can acquire strategic resources more efficiently; they can formulate industry norms in network organizations, regulate competition in supplier networks, and reduce vicious competition in networks, promoting healthy competition among members of the network and winning the respect of network members; at the same time, each member innovates in accordance with the technical standards and industry norms formulated by the core enterprise, and the knowledge and components generated in the innovation process are added to the core enterprise product innovation process to improve the innovation performance of enterprises.

Core enterprises should encourage and stimulate the innovative behavior of suppliers. Due to the arduousness of innovation activities, core enterprises are often difficult to complete innovation activities from raw materials to technological processes to finished products alone. Therefore, it is necessary for core enterprises to encourage the innovative behavior of suppliers, to stimulate the intention of suppliers to actively serve the innovation activities of core enterprises, and to encourage suppliers to innovate in key components and key basic materials, so that the innovation activities of core enterprises can be completed.

Core enterprises should guide and participate in the construction of supplier networks. Supplier network is an important source for core enterprises to obtain resources and obtain sustainable competitive advantage. However, for core enterprises, how to play the role and value of supplier network is more important. This requires core enterprises to exert their subjective initiative, actively participate in the process of forming and developing supplier networks, make good use of supplier network relationships, and fully acquire and utilize supplier resources and capabilities, thereby promoting breakthrough innovations of core enterprises. 
From the perspective of power dependence, this paper deeply analyzes the relationship among core enterprises' network power, supplier innovation ability and breakthrough innovation, and further enriches the research on supplier innovation utilization mechanism and network power theory. However, there are still some shortcomings in this study: (a) The selection of samples is limited. The representativeness, scope and quantity of the samples selected in this paper still have room for expansion, and follow-up research can be further improved and deepened. (b) This study uses supplier innovation ability as an intermediary, and only discusses the path mechanism between network power and breakthrough innovation in supplier networks. Future research can explore the path mechanism between network power and breakthrough innovation in other networks.

\section{Acknowledgement}

This work is supported by the Fund projects: Jiangsu Province Postgraduate Research and Practice Innovation Project (KYCX21_1293).

\section{References}

[1] Abemathy, W. Utterback, J. Patterns of innovation in technology[J]. Technology Review, 1978, 80(7): 40-47.

[2] Akbar Zaheer, Geoffrey G. Bell. Benefiting from network position: Firm capabilities, structural holes and performance $[J]$. Strategic Management Journal, 2005, 26: 809-825.

[3] Baron, R. M., Kenny, D. A.. The moderator-mediator variable distinction in social psychological research: conceptual, strategic, and statistical considerations[J]. Journal of Personality and Social Psychology, 1986, 51(6): 1173-1182.

[4] Dai Wanliang, Li Qingman. The influence of market orientation on the diffusion of technical standards in the context of industrial clusters - A moderated mediating effect[J]. Science and Technology Progress and Countermeasures, 2016, 33(23): 51-56.

[5] Dang Xinghua, Sun Yonglei. Research on the influence of technological innovation network location on network practices-Inter-organizational trust as a mediating variable[J]. Scientific Research Management, 2013, 34(04): 1-8.

[6] Fang Lan, Guo Yang, Wang Ning. Core enterprise network power, relationship commitment and weak enterprise performance: The perspective of network power erosion[J]. Science and Technology Management Research, 2018, 38(19): 216-225.

[7] Gemünden H G, Ritter T, Heydebreck P. Network configuration and innovation success: An empirical analysis in German high-tech industries[J]. International Journal of Research in Marketing, 1996, 13(5): 449-462.

[8] Guan Jun, Xu Jianzhong, Lin Yan. Research on the relationship between cross-border search, network routines, dual capabilities and innovation performance [J]. Management Review, 2019, 31(12): 61-72.

[9] Han Ying, Chen Guohong, Research on the relationship between network power and innovation performance of cluster enterprises-Based on the mediating role of ambidextrous knowledge sharing behavior[J]. Journal of Management, 2016, 13(6): 855-862.
[10] Huang Yuzhou, Li Suicheng, Li Gang. Research on the Influence of Supplier Innovation on improving the independent innovation capability of equipment manufacturing enterprises[J]. Soft Science, 2013, 27(10): 68-73.

[11] Ireland. D., Webb, J.W. A multi-theoretic perspective on trust and power in strategic supply chains[J]. Journal of Operations Management, 2007, 25(2): 82-497.

[12] Kähkönen A K. The influence of power position on the depth of collaboration[J]. Supply Chain Management: An International Journal, 2014, 19(1): 17-30.

[13] Keskin, H.. Market Orientation, Learning Orientation, and Innovation Capabilities in SMEs: An extended model[J]. European Journal of Innovation Management, 2006, 9 (4): 396-417.

[14] Li Na, Li Suicheng, Cui Hexun. Suppliers' innovative utilization mechanism: The role of enterprise networking behavior[J]. Nankai Management Review, 2018, 21(01): 39-53.

[15] Li Na, Li Suicheng. Utilizing supplier innovation to achieve product innovation: From the perspective of relationship management[J]. Soft Science, 2017, 31(01): 58-62.

[16] Li Rui, Tao Qiuyan. The influence of the relationship between the contracting party and the supplier on the innovation ability of suppliers[J]. Technology and Economics, 2016, 35(05): 53-61.

[17] Ma Lan, An Liren. The influence mechanism of cooperation experience, absorptive capacity, and network power on enterprise innovation performance: Based on the perspective of organizational learning $[\mathrm{J}]$. Science and Technology Progress and Countermeasures, 2016, 33(01): 81-87.

[18] Owen-Smith, J., Powell, W. W.. Knowledge networks as channels and conduits: The effects of spillovers in the Boston biotechnology community[J]. Organization Science, 2004, 15(1): 5-21.

[19] Phelps Corey C.A. longitudinal study of the influence of alliance network structure and composition on firm exploratory innovation[J]. Academy of Management Journal,2010,53(4):890-913.

[20] Pulles N J, Veldman J, Schiele H. Identifying innovative suppliers in business networks: An empirical study[J]. Industrial Marketing Management, 2014(3): 409-418.

[21] Sun Guoqiang, Dou Jie, Ji Yingdong. Review and prospect of network power determinism research $[\mathrm{J}]$. Science and Technology Management Research, 2018, 38(01): 261-266.

[22] Sun Guoqiang, Ji Yingdong, Zhang Baojian, Xu Lifeng. Network structure, network power and cooperative behavior-Based on the micro evidence of the support network in the miss world tourism competition[J]. Nankai Management Review, 2016, 19(01): 43-53.

[23] Sun Guoqiang, Wang Yanfang, Ji Yingdong. Review and prospect of the evolution theory of network power[J]. East China Economic Management, 2018, 32(03): 176-184.

[24] Utterback J M. Mastering the dynamics of innovation: How companies can seize opportunities in the face of technological change[M]. Boston: Harvard Business School Press, 1994.

[25] Wang Hecheng, Li Xin. The impact of enterprise network embeddedness on innovation performance: The 
mediating effect of network power and the moderating effect of absorptive capacity[J]. Science and Technology Management Research, 2019, 39(21): 122-129.

[26] Wang Qin. The power base of network governance: A cross-case study[J]. Nankai Management Review, 2012, 15(03): 91-100.

[27] Xiande Zhaoa, Baofeng Huob, Barbara B. Flynnc, etc. The impact of power and relationship commitment on the integration between manufacturers and customers in a supply chain[J]. Journal of Operations Management, 2008, 26: 368-388.

[28] You Daming, Ma Beiling. Research on the influence of relational fit on knowledge transfer and breakthrough innovation performance $[\mathrm{J}]$. Systems Engineering Theory and Practice, 2014, 34(12): 3103-3112.

[29] Zhang Gongyi, Xi Yujuan, Guo Xin. Research on the influence of enterprise network on breakthrough innovation[J]. Economics, 2017(09): 75-82.

[30] Zhao Ling, Tian Zengrui, Chang Beiquan. Research on the influence mechanism of entrepreneurial resource integration on company entrepreneurship[J]. Science and Technology Progress and Countermeasures, 2020, 37(06): 27-36.

[31] Zhou K Z, Yim C K B, Tse D K. The effects of strategic orientations on technology and market-based break through innovations[J]. Journal of Marketing, 2005, 69(4): 42-60.

\section{Author Profile}

Lu Chen (1997-), a master student of Nanjing Normal University Business School. Her research direction is technology innovation management.

Jinsheng Li (1974-); Ph.D., professor and doctoral supervisor of the Business School of Nanjing Normal University. His research direction is technology innovation management. 